\title{
Warehousing and transportation logistics of mango in Colombia: A sustem dụnamics model
}

\author{
Logística en almacenamiento y transporte de mango en Colombia: Un \\ modelo en dinámica de sistemas
}

Logística em armazenamento e transporte de manga na Colômbia: Um modelo em dinâmica de sistemas

Fecha de recepción: 26 de mayo de 2016

Fecha de aprobación: 12 de agosto de 2016

Javier Arturo Orjuela-Castro* Milton Mauricio Herrera-Ramírez Wilson Adarme-Jaimes

\section{Abstract}

This paper evaluates the incidence of packing asymmetries, resulted from the use of heterogeneous packaging materials by different mango supply chain actors in Colombia, on performance measures of inventory, transportation, and quality. A system dynamics model was proposed based on the literature review on inventory and transportation logistics, the studies on asymmetries in supply chain, packing, and packaging, and the results of the characterization of the fruit chain logistics in various departments of Colombia from 2012 to 2013. We used the proposed model to test the following hypothesis: "The asymmetry in the packaging, derived from the actors' individual management, creates inefficiencies that may be avoid if the packaging of the fruit is done thinking on the chain". The developed simulation model allowed us to prove the proposed dynamic hypothesis. Forrester's model includes four echelons for the supply chain: production, processing, wholesale, and retail, as well as warehousing, transportation and information.

Keywords: mango; mango packaging; mango transportation; performance; supply chain; system dynamics.

* Ph.D.(c) Universidad Distrital "Francisco José de Caldas" (Bogotá-Distrito Capital, Colombia). jorjuela@udistrital.edu.co.

** Ph.D.(c) Universidad Piloto (Bogotá-Distrito Capital, Colombia).milton-herrera@upc.edu.co.

*** Ph.D. Universidad Nacional de Colombia (Bogotá-Distrito Capital, Colombia).wadarmej@unal.edu.co. 


\section{Resumen}

El artículo evalúa las incidencias de las asimetrías derivadas del manejo de diversos tipos de embalaje (material y tamaño heterogéneo) por los diferentes agentes de la cadena de suministro de mango en Colombia, en las medidas de desempeño de inventarios, transporte y calidad. A partir de la revisión de la literatura sobre logística de inventarios y transporte y sobre asimetrías en las cadenas alimentarias y en el empaque-embalaje de la cadena de frutas, y de una caracterización de la logística de la cadena de suministro de frutas en varios departamentos de Colombia, durante 2012-2013, se elabora un modelo en dinámica de sistemas que permite evaluar la hipótesis: "La asimetría en el embalaje, derivada de la gestión individual de sus actores, genera ineficiencias que son evitables si estos embalaran pensando en la cadena". El modelo de simulación desarrollado permitió comprobar la hipótesis dinámica planteada. El modelo de Forrester diseñado incluye cuatro eslabones de la cadena de suministro: producción, transformación, mayoristas y minoristas, así como almacenes, transporte e información.

Palabras clave: almacenamiento de mango; cadena de suministro; dinámica de sistemas; embalajes; mango; transporte de mango.

\section{Resumo}

$\mathrm{O}$ artigo avalia as incidências das assimetrias derivadas do manejo de diversos tipos de embalagem (material e tamanho heterogêneo) pelos diferentes agentes da cadeia de fornecimento de manga na Colômbia, nas medidas de desempenho de inventários, transporte e qualidade. A partir da revisão da literatura sobre logística de inventários e transporte e sobre assimetrias nas cadeias alimentares e no embalagem-empacotamento da cadeia de frutas, e de uma caracterização da logística da cadeia de fornecimento de frutas em vários Estados da Colômbia, durante 2012-2013, elabora-se um modelo em dinâmica de sistemas que permite avaliar a hipótese: "A assimetria no empacotamento, derivada da gestão individual de seus atores, gera ineficiências que são evitáveis se estes embalaram pensando na cadeia". O modelo de simulação desenvolvido permitiu comprovar a hipótese dinâmica planteada. O modelo de Forrester desenhado inclui quatro elos da cadeia de fornecimento: produção, transformação, atacadistas e varejistas, assim como depósitos, transporte e informação.

Palavras chave: armazenamento de manga; cadeia de fornecimento; dinâmica de sistemas; empacotamento; manga; transporte de manga.

Cómo citar este artículo:

J. A. Orjuela-Castro, M. M. Herrera-Ramírez, and W. Adarme-Jaimes, "Warehousing and transportation logistics of mango in Colombia: A system dynamics model," Rev. Fac. Ing., vol. 26 (44), pp. 73-86, Ene. 2017. 


\section{INTRODUCTION}

In an era of healthy foods, the fresh food consumers' expectations have increased, being freshness a differentiator nowadays. This global interest has led to an increase in the demand for fresh or unprocessed fruits and vegetables, which meets consumers' standards for high quality and nutrition [1]. Globalization has resulted in greater distances between food production and consumption sites due to the effect of productive specialization. Therefore, the integration of production and distribution along the food chain is required [2]. However, it is essential to investigate the conditions under which this integration is beneficial because it may generates high costs or imprecise flows of information [3]. In the case of supply chain (SC), it is appropriate and necessary to have adequate coordination between processes and actors to potentiate the development of the sector.

Integration can be confused with cooperation, coordination, or collaboration; however, there are differences between these concepts. Cooperation is the act of working together for a common goal $[4,5]$; coordination is a more direct and active cooperation [4]; and collaboration is working together for a particular purpose with a shared vision [6]. Despite the differences between these concepts, cooperation, coordination, and collaboration are complementary to each other [7]. Food chains have losses due to failures in the logistics system; and although they can vary depending on the structure of the $\mathrm{SC}$, it is estimated that one third of global food production is wasted or lost annually [8]. Colombia is no exception, although it has promoted policies for the articulation of the processes, and the relationships between the socio-economic agents [9]. The SC involves subsets of elements that considered in isolation hinder the understanding of the totality of the economic activities connected with food [10]. In this sense, coordination between the agents involved in the logistics processes is necessary [11].

The chains with perishable products, like fruits, require special care [12]. The quality of the fruit depends on the pre-harvest conditions, and the postharvest management [13]. Fresh foods have special characteristics given the loss of food due to the continuous change of their organoleptic characteristics through the chain. Therefore, it is essential to monitor and control the logistics processes for which technologies of traceability can be used [14]. The logistical problems in Colombia are of a general and structural nature. The Ministry of Agriculture and Rural Development in Colombia noted that the country has comparative advantages for fruit cultivation [15]; for instance, currently the fruits chain is self-sustained and will be sustainable in the future. However, the losses in perishable goods such as fruit can reach $40 \%$, out of which $20 \%$ to $25 \%$ are due to logistics practices.

This study addresses the impact of asymmetries in packing on the efficiency of inventories, transportation, and product quality, given the heterogeneity of the Colombian fruit chain actors' logistical practices. Each actor in the mango chain is used to different packaging types. Producers use wooden or plastic boxes depending on availability, whereas the other actors (upstream) repack the product depending on consumer's requirements. These asymmetries in the packing logistics, caused by the different actors in the Colombian mango chain using different packaging materials, have a negative impact on the performance of inventories, transportation, and quality.

The incidence of different means of packaging on the efficiency of the mango chain in Colombia has been poorly studied. In very few cases, the cold chain is used, although the norms NTC 1266-2 and 5422 have been proposed, and their use by the actors of the chain has been observed. The dominant feature is the use of different means of packaging by each actor in the SC, who pack according to the resources availability or the requirements, without thinking of the chain needs. This implies that in the mango transportation chain, from farm to consumer, several changes are made to packaging, thereby generating avoidable inefficiencies of inventories, transportation, and loss of quality.

This article is structured into four chapters. The first chapter reviews the literature, beginning with the inventory and transportation logistics in the food chain, moving onto studies of asymmetries, and concluding with packing and packaging in the fruit chain. The second chapter covers the methods, which include the model created by Forrester [48], and its experimental design in the mango chain. Chapter three describes how the model was developed. Chapter four describes the results and discussion, which show the incidence of asymmetries in the packaging and performance measures of inventories, transportation, and quality. The paper closes with conclusions and future work. 


\section{LITERATURE REVIEW}

The literature revision included studies on inventory, storage, and transportation issues, with an emphasis on perishable products (i.e., fruits), their packing and packaging.

\section{A. Transport logistics of inventories in the food}

\section{chain}

Fresh fruits are susceptible to mechanical damage during harvest, packaging and transport, which can result in a substantial reduction in quality [16]. Foodstuffs often need the technologies of inventories and advanced transportation. Nahmias [17] reviewed the literature on inventories in perishables, looking at perishable products with fixed lives (stochastic and deterministic demand), and random variables (with periodic review and exponential decay), as well as control rules for certain types of inventories with perishable products. The studies reviewed by Nahmias [17] revealed that a considerable number of problems on perishable products still remain unresolved; for instance, an extremely difficult problem is the continuing review for products with fixed lives and positive lead-time. Nahmias suggested that a control rule based on the expected life of the inventory at hand could be more appropriate for the perishable goods than one based on the number of items in stock.

The inventories of perishable products involve timesensitive orders, with complete orders delivered shortly after being produced. Consequently, there is little inventory level of finished products in the supply chain, so the production and distribution are intimately related, and must be programmed together to achieve the desired performance with on-time delivery, and with a minimal total cost [18]. For perishable goods, in moments of short supply, retailers increase prices or generate discounts due to deterioration; therefore, the overall performance of the supply chain is greatly affected by the decision-making in this link [19]. If the inventories are large, there is the likelihood of damage due to decomposition, and with a minimum inventory of products, there is the possibility of scarcity when demand exceeds the inventory [20].

Several models have been proposed to manage inventories of food products. Arango et al. [21] proposed a Vendor Managed Inventory (VMI) model in the $\mathrm{SC}$ process, analyzing the total cost of the SC and the benefits of VMI implementation in the bakers' sector. In the same sense, others have proposed models of inventories for products that deteriorate. Balkhia et al. [22], Hou [23] and Yu et al. [2] have studied distribution systems in order to minimize the total costs of warehousing and transportation, maintaining the quality requirements of the products; furthermore, they developed mathematical models with the production, harvesting, and decomposition process of fresh products. Ahumada et al. [24] discussed the packaging and distribution of fresh products, including the limitations of warehouses and a loss function in the objective function.

Kopanos et al. [25] studied the problem of planning the production and distribution in the food processing industry at multiple sites, and in a mixed-integer programming framework. Yu et al. [2] developed a model in the supply network of fresh and perishable foods. Liu et al. [26] created a model of multiple periods, which applies to perishable products, and enables a unified treatment of inventory, production, and transportation, as explicit flows in the network, by using a continuous time approach for multiple periods and transportation networks, including delay times. Several aspects of the food chain need to be evaluated regarding the deterioration of fresh fruit during transport and handling [27], including impact damage, compression, abrasion, and puncture. To accomplish this, quantitative assessments of mechanical damage are conducted, such as measuring the effects of the environment and storage time, the impact energy, the place of impact, the related type, the physical variables of maturity, the $\mathrm{pH}$ of the fruit during transport [16], the effect of the vibration level, the type of container [28], and the location in the truck [29].

\section{B. Asymmetries in the supply chain}

Supply chains are skewed by nature given their heterogeneity and capabilities in warehousing and transportation logistics [26], which in turn affect aspects of product differentiation and quality. In terms of inventories, Reyes [30] looked at the problem of the newspaper sellers as it relates to two-step manufacturer-distributors in the $\mathrm{SC}$ with asymmetrical information markets. In this scenario, the retailer has better knowledge of the market demand, while the other actors in the chain (downstream) simply perceive it. Several studies have shown that different strategies can decrease the effects of this asymmetry. This may 
be a case of asymmetry in the quality information [31], which many have tried to overcome through contracts or agreements between the chain links to share risk information and inventory planning [32]. However, this culture of contracts, as a strategy, does not exist in the strings of foodstuff environment in countries like Colombia. The development of coordination or cooperation can be an appropriate measure in developing countries.

\section{Packing and packaging in the fruit chain}

Packing and packaging are fundamental in the food's life, and play an important role in the fruit agro-industry. From a tactical point of view, packaging is the industry's most important way of maintaining the fresh fruit SC [33]. Maintaining the fruit quality in the SC depends on good practices in farm and crop management, packaging operations, postharvest treatments, temperature management, transportation conditions, and warehousing [34]. Avoiding contamination of fresh products, which may happen either from pre- to post-harvest, or from farm to table, is a global concern [35]. Therefore, the packing with modified atmosphere (MAP) [36], and the packaging with controlled atmosphere (CA) $[37,38]$ have been used to preserve fruits in the $\mathrm{SC}$, and to conserve their healthy features [39].

Choosing between several types of materials, designs, and constructions to develop packages that can carry and store perishables with minimal damage and environmental impact is a challenge. There are several containers designed and used to package and ship fresh fruits and vegetables. The most commonly used materials in the world are reusable plastic and corrugated cardboard boxes. Plastic, which has been demonstrated has less environmental impact, is widely used in Europe, while the cardboard is used more in the United States [40]. In Colombia, studies have been conducted to establish the packaging for export products [41]. Colombia has developed the norm NTC 5422 [42], which establishes the packaging and packing requirements that need to be met to preserve the quality of fresh fruits and vegetables. Efforts have been made to establish technologies to conserve fruits in the postharvest, such as the study on the influence of temperature and storage time on the preservation of mango [43], the use of modified atmospheres in the packing and storage of mangoes, and comparisons between the use of corrugated cardboard and plastic containers for the protection of mangoes during distribution [46]. Additionally, there are specific rules for certain fruits, as is the case for the norm NTC 12662 for specifications of the mango packaging [45].

\section{Methods}

Although all Colombian fruits have the asymmetry problem in packaging, a specific fruit was selected for this study. To select the fruit, the analytical hierarchy process was used, taking into account the following factors: national production in tons, cultivated area in hectares, yields in tons per hectare, and number of far$\mathrm{ms}$ and families who cultivate the fruit. Based on this, the fruit selected was mango. Subsequently, the variables transport, inventories, and quality were selected as logistical and performance measures. The variables were established and applied to the data collection instruments, surveys, and structured observations. The information from interviews in the various links was gathered during 2012 and 2013 [47] (Table 1).

\section{TABLE 1}

Amount of Companies Surveyed Per Link

\begin{tabular}{|l|c|l|}
\hline \multicolumn{1}{|c|}{ Chain Link } & Quantity & \multicolumn{1}{c|}{ Department } \\
\hline Fresh fruit producers & 5 & Cundinamarca, Casanare, Meta. \\
\hline Agribusiness (transformer) & 5 & Bogotá, Armenia, Manizales, Boyacá and national. \\
\hline Market wholesalers & 4 & Bogotá, Cundinamarca, national. \\
\hline Retail trader & 5 & Bogotá, national. \\
\hline
\end{tabular}

The high number of published articles on system dynamics modeling shows the importance of this tool to analyze the supply chain management. The seminal publication Dynamic Industrial [48] is relevant to the SC management field nowadays [49]. A simulation model in dynamics systems was the method used to analyze inefficiencies in the mango supply chain caused by asymmetries in packaging. The model was designed using the methodology proposed by Forrester 
[48], and Morecroft and Sterman [50] in the iThink software.

\section{Model}

The proposed model seeks to answer the following question: Over time, what is the behavior of the inefficiency in inventories, transportation, and quality in the mango supply chain, which is caused by the asymmetries in packaging generated by the actors of the chain? In this regard, the following dynamic hypothesis was proposed for the developed simulation model: the asymmetry in the packaging derived from the actors' individual management creates avoidable inefficiencies in inventories and transportation in the mango supply chain (SC-M). The structure of the simulation was developed using the methodology of system dynamics as presented below.

\section{A. Simulation structure}

The structure of the simulation model has seven sectors (Fig. 1): fruit producer, agribusiness, marketer wholesaler, marketer retailer, information, transport, and store. The purpose of organizing the model structure in sectors is determining the impact of packaging asymmetries in the transport, inventory, and quality for each actor, and for the whole chain.

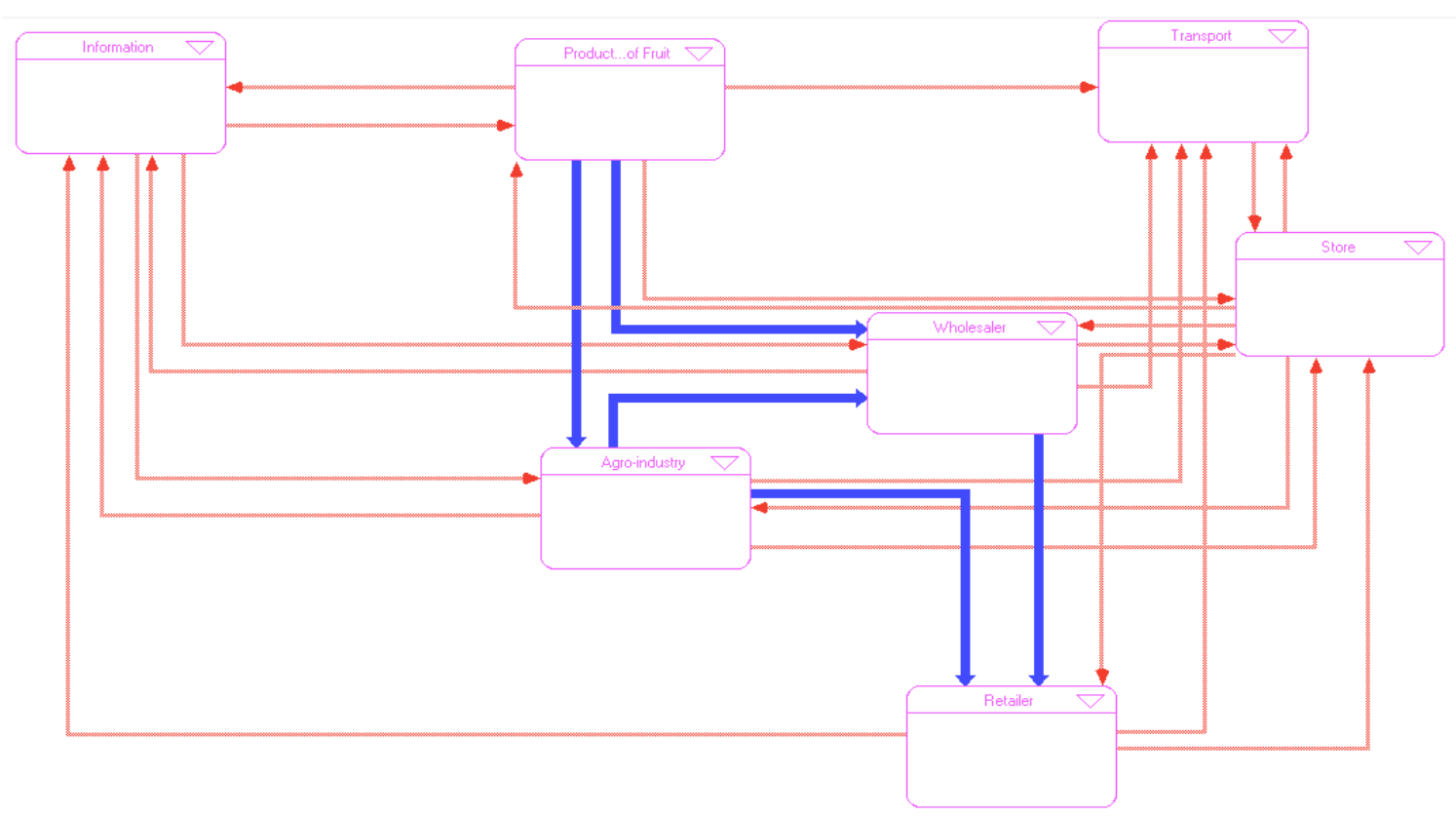

Fig. 1. Structure of the model of the fruits chain.

The material flow (thick blue line in Figure 1) connects the fruit producer with the agribusiness and the marketer wholesaler; and the agro-industry and the wholesale marketer with the marketer retailer. The red lines represent the information flow that fuel each one of the model sectors (actors). In this way, the flow of information in the fruit (Mango) SC connects from the resources (packaging, transportation and warehouse). The developed simulation model allows us to analyze the behavior of the packaging asymmetries in the inventory and transportation, through the stock and flow diagram, regulated by the type of packaging, and the time spent by each actor (Figure 2). 


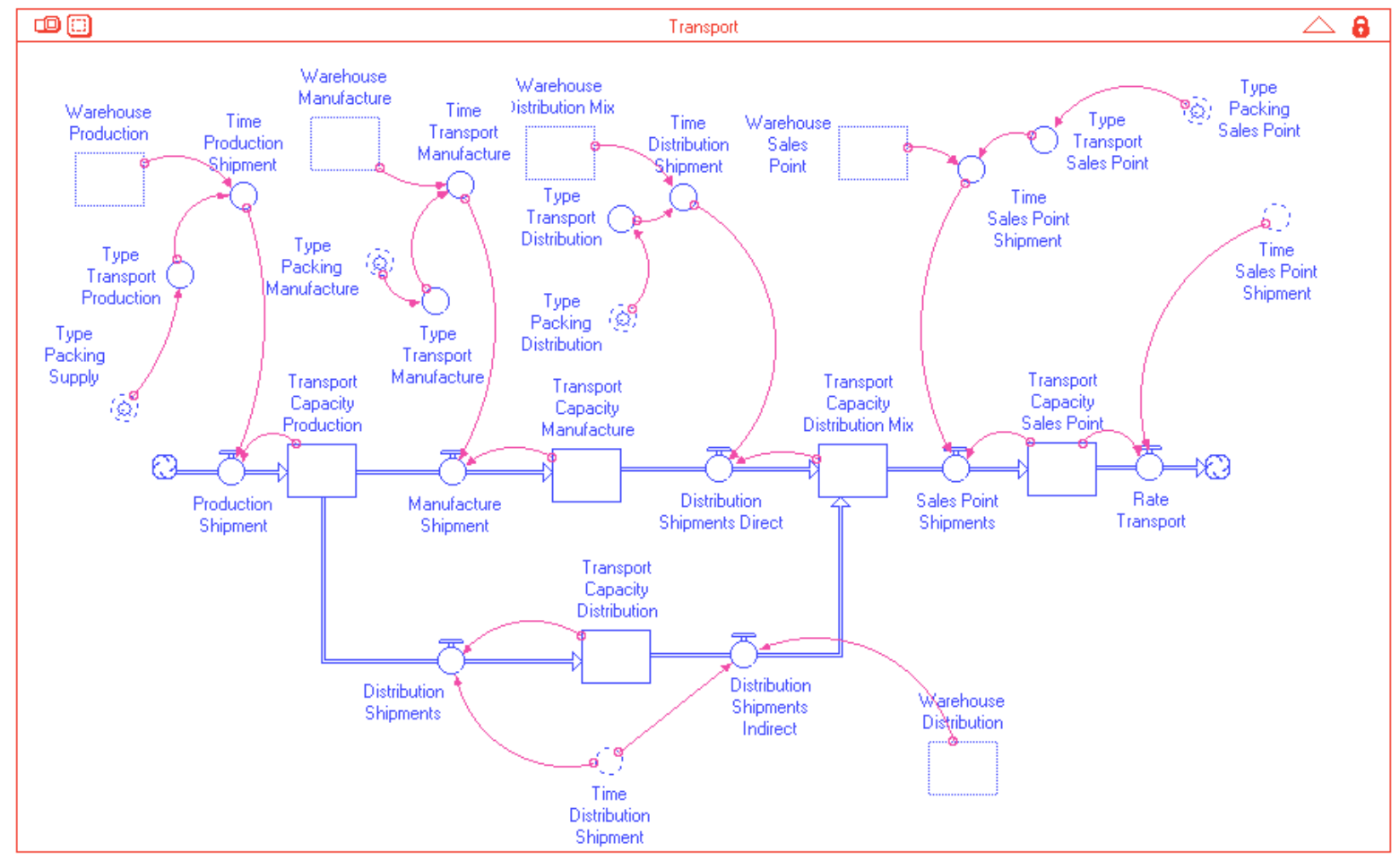

Fig. 2. Stock and flow diagram of the transport sector.

\section{RESUlts AND Discussion}

\section{A. Input data}

In order to estimate the parameters of the input variables of the model, and the model behavior, we identified the central measures and dispersion of the variable demand, according to the mango historical production [51, 52]. Table 2 shows the sample size, median, and standard deviation used as input parameters in the simulation.

\section{TABLE 2}

Statistical Analysis of the Demand

\begin{tabular}{|l|c|c|c|c|}
\hline & Sample & Mean & Standard Deviation & Standard Half of the Error \\
\hline Mango & 120 & 213,75 & 80,191 & 23,149 \\
\hline
\end{tabular}

The technical standard packing capacity of mango (common and sugar) for each actor in the SC was used (Table 3), according to the types and frequency of packaging used by agents (Table 4). This input parameter produces a decrease in postharvest losses due to failures in the logistics system to simulate the quality of products stored by actors in the SC.

TABLE 3

Technical Standard Packing Capacity of Mango

\begin{tabular}{|l|c|c|c|c|}
\hline & Wooden box & Corrugated box & Plastic cage & Package \\
\hline Mango & $39 * 49 * 26(45)$ & $35 * 56 * 29(45)$ & $36 * 52 * 29(45)$ & $50 * 100 * 40(120)$ \\
\hline \multicolumn{5}{|c}{ Note: Length*Height*Width in centimeters, (Weight) in pounds }
\end{tabular}


Table 4 shows the percentage of time spent on packaging between brackets, allowing for the transport flow simulation between $t$ actors of the SC.

\section{TABLE 4}

FREQUENCY OF USE OF DIFFERENT PACKAGING TYPES BY ACTOR, AND THE PERCENTAGE OF TIME SPENT IN MANGO PACKAGING ACCORDING TO THE TYPE OF PACKAGING (RATIO) [47]

\begin{tabular}{|c|c|c|c|c|}
\hline & \multicolumn{4}{|c|}{ Type of Packaging } \\
\hline Supply Chain Actors & $\begin{array}{c}\text { Wooden box } \\
(1)\end{array}$ & $\begin{array}{c}\text { Corrugated box } \\
(2)\end{array}$ & $\begin{array}{c}\text { Plastic cage } \\
(3)\end{array}$ & $\begin{array}{c}\text { Package } \\
(4)\end{array}$ \\
\hline Producer & - & $12(0,1)$ & $25(0,2)$ & $70(0,7)$ \\
\hline Agribusiness (transformer) & - & $12(0,4)$ & $25(0,6)$ & - \\
\hline Market wholesalers & $12(0,1)$ & $12(0,1)$ & $25(0,2)$ & $60(0,6)$ \\
\hline Retail trader & $12(0,4)$ & - & $25(0,6)$ & - \\
\hline
\end{tabular}

\section{B. Experimental design}

We conducted 82 random simulation tests, and combined the following different types of packaging used in the productive mango SC: wooden boxes (1), corrugated boxes (2), plastic cages (3), and packages (4). We selected 16 simulations and tested them according to the technical standard of mango packing capacity, which identifies the type of packaging used by each actor of the SC (see Table 4). The results were submitted to tests of homogeneity of variances (statistical Levene), followed by analysis of variance (ANOVA) to test for the ability to store and the time spent on the Mango packaging.

Evidence of the variable capacity of warehouses allows to reject the null hypothesis $(p<0.05)$, which means that at least one of the actors in the SC has a different warehouse capacity than the others. Therefore, the variable capacity of warehouses is determined by combining packaging simulations and their influence on storage ability. However, the transportation time associated with the packaging shows a $\mathrm{p}<0.05$ and a Levene statistic with a value of significance of 0.008 , indicating that it does not rejects the hypothesis of equality of means and variances between the actors of the SC.

The proposed experimental design shows the differences among the simulation values obtained by each actor in the $\mathrm{SC}$ associated with warehouse and transport. We simulated 16 possible packaging combinations for each actor in the SC, according to the type of packaging used by most actors. The results of the performance measures were used to compare the behavior of the simulation with the proposed dynamic hypothesis (Table 5).

\section{TABLE 5}

Simulation Results for 16 Different Combinations of Packaging by SC Actors

\begin{tabular}{|c|c|c|c|c|c|c|c|c|c|c|c|c|}
\hline \multirow[b]{2}{*}{ Simulation } & \multicolumn{4}{|c|}{$\begin{array}{c}\text { Combination of Packaging for each Actor } \\
\text { in the SC }\end{array}$} & \multicolumn{4}{|c|}{ Variables Response: Storage Capacity (t) } & \multicolumn{4}{|c|}{ Results Time Packaging for Transport (\%) } \\
\hline & Producer & $\begin{array}{l}\text { Agribusiness } \\
\text { (transformer) }\end{array}$ & $\begin{array}{c}\text { Market } \\
\text { wholesalers }\end{array}$ & $\begin{array}{l}\text { Retail } \\
\text { trader }\end{array}$ & Producer & $\begin{array}{l}\text { Agribusiness } \\
\text { (transformer) }\end{array}$ & $\begin{array}{c}\text { Market } \\
\text { wholesalers }\end{array}$ & $\begin{array}{l}\text { Retail } \\
\text { trader }\end{array}$ & Producer & $\begin{array}{l}\text { Agribusiness } \\
\text { (transformer) }\end{array}$ & $\begin{array}{c}\text { Market } \\
\text { wholesalers }\end{array}$ & $\begin{array}{l}\text { Retail } \\
\text { trader }\end{array}$ \\
\hline 5 & 2 & 2 & 1 & 1 & 109,7 & 104,99 & 115,9 & 120,3 & 2,2 & 2,62 & 2,9 & 2,41 \\
\hline 14 & 2 & 2 & 2 & 1 & 109,7 & 105,05 & 115,8 & 120,5 & 2,2 & 2,63 & 2,89 & 3,01 \\
\hline 15 & 2 & 3 & 3 & 3 & 107,6 & 103,39 & 109,7 & 120,5 & 3,59 & 3,45 & 2,74 & 4,02 \\
\hline 16 & 2 & 2 & 3 & 3 & 110,3 & 104,62 & 115,8 & 120,5 & 3,68 & 2,62 & 2,89 & 4,02 \\
\hline 17 & 2 & 2 & 2 & 3 & 110,3 & 104,61 & 115,7 & 120,4 & 3,68 & 2,62 & 2,89 & 3,01 \\
\hline 21 & 3 & 3 & 3 & 3 & 106,9 & 104,03 & 111,8 & 120,4 & 3,56 & 3,47 & 3,73 & 4,02 \\
\hline
\end{tabular}


Javier Arturo Orjuela-Castro - Milton Mauricio Herrera-Ramírez - Wilson Adarme-Jaimes

\begin{tabular}{|c|c|c|c|c|c|c|c|c|c|c|c|c|}
\hline \multirow[b]{2}{*}{ Simulation } & \multicolumn{4}{|c|}{$\begin{array}{c}\text { Combination of Packaging for each Actor } \\
\text { in the SC }\end{array}$} & \multicolumn{4}{|c|}{ Variables Response: Storage Capacity (t) } & \multicolumn{4}{|c|}{ Results Time Packaging for Transport (\%) } \\
\hline & Producer & $\begin{array}{l}\text { Agribusiness } \\
\text { (transformer) }\end{array}$ & $\begin{array}{c}\text { Market } \\
\text { wholesalers }\end{array}$ & $\begin{array}{l}\text { Retail } \\
\text { trader }\end{array}$ & Producer & $\begin{array}{l}\text { Agribusiness } \\
\text { (transformer) }\end{array}$ & $\begin{array}{c}\text { Market } \\
\text { wholesalers }\end{array}$ & $\begin{array}{l}\text { Retail } \\
\text { trader }\end{array}$ & Producer & $\begin{array}{l}\text { Agribusiness } \\
\text { (transformer) }\end{array}$ & $\begin{array}{c}\text { Market } \\
\text { wholesalers }\end{array}$ & $\begin{array}{l}\text { Retail } \\
\text { trader }\end{array}$ \\
\hline 23 & 3 & 3 & 1 & 1 & 105,7 & 104,97 & 113 & 120,2 & 2,11 & 3,5 & 3,77 & 2,41 \\
\hline 24 & 3 & 3 & 3 & 1 & 105,7 & 105,17 & 112,9 & 120,5 & 2,11 & 3,51 & 3,76 & 4,02 \\
\hline 38 & 4 & 3 & 3 & 3 & 106,1 & 104,45 & 114,2 & 120,3 & 3,54 & 3,48 & 5,71 & 4,01 \\
\hline 42 & 3 & 2 & 3 & 3 & 109,8 & 104,91 & 117,9 & 120,4 & 3,66 & 2,62 & 3,93 & 4,02 \\
\hline 54 & 3 & 3 & 1 & 3 & 106,9 & 103,93 & 112 & 120,1 & 3,56 & 3,46 & 3,73 & 2,4 \\
\hline 57 & 3 & 3 & 2 & 3 & 106,9 & 103,99 & 111,8 & 120,3 & 3,56 & 3,47 & 3,73 & 3,01 \\
\hline 64 & 3 & 3 & 4 & 3 & 106,9 & 104,06 & 111,9 & 120,4 & 3,56 & 3,47 & 3,73 & 6,02 \\
\hline 77 & 4 & 2 & 3 & 1 & 107,3 & 106,75 & 128,8 & 120,3 & 2,15 & 2,67 & 6,44 & 4,01 \\
\hline 79 & 4 & 2 & 1 & 3 & 109,0 & 104,32 & 127,4 & 119,7 & 3,63 & 2,61 & 6,37 & 2,39 \\
\hline 82 & 4 & 3 & 2 & 1 & 104,3 & 105,56 & 116,5 & 120,2 & 2,09 & 3,52 & 5,83 & 3,01 \\
\hline
\end{tabular}

\section{Performance measures}

The performance measures in the simulation were seasonal inventory average, average transportation flow time, and percentage of quality and traceability designed for the warehouse and transport sectors (Table 6). In the first sector, the average seasonal inventory was calculated, for each simulation run, as a measure of performance of the SC store capacity. The results show that the minimum average seasonal inventory was obtained in combination 3 (producer: corrugated boxes; agro-industry: plastic cage; wholesale: plastic baskets; and retail: plastic cage), and simulation run 15 with a value of 46.28 tons (Table 6).

\section{TABLE 6}

SEAsonal InVEntory Averages

\begin{tabular}{|c|c|c|c|c|}
\hline $\begin{array}{c}\text { Combination } \\
\text { Packaging }\end{array}$ & $\begin{array}{c}\text { Simulation } \\
\text { Run }\end{array}$ & $\begin{array}{c}\text { Seasonal } \\
\text { Inventory } \\
\text { Average } \\
\text { (t) }\end{array}$ & $\begin{array}{c}\text { Average } \\
\text { Flow Time } \\
\text { Transport }\end{array}$ & $\begin{array}{c}\text { Average } \\
\text { Quality and } \\
\text { Traceability } \\
\mathbf{( \% )}\end{array}$ \\
\hline 1 & 13 & 47,17 & 2,53 & 0,83 \\
\hline 2 & 14 & 47,19 & 2,68 & 0,83 \\
\hline 3 & 15 & 46,28 & 3,45 & 0,82 \\
\hline 4 & 16 & 47,22 & 3,30 & 0,83 \\
\hline 5 & 17 & 47,20 & 3,05 & 0,82 \\
\hline 6 & 21 & 46,41 & 3,70 & 0,82 \\
\hline 7 & 23 & 46,41 & 2,95 & 0,83 \\
\hline 8 & 24 & 46,46 & 3,35 & 0,83 \\
\hline 9 & 38 & 46,53 & 4,19 & 0,82 \\
\hline 10 & 42 & 47,36 & 3,56 & 0,82 \\
\hline 11 & 54 & 46,37 & 3,29 & 0,82 \\
\hline 12 & 57 & 46,39 & 3,44 & 0,81 \\
\hline 13 & 64 & 46,42 & 4,20 & 0,81 \\
\hline 14 & 77 & 48,10 & 3,82 & 0,80 \\
\hline 15 & 79 & 47,91 & 3,75 & 0,82 \\
\hline 16 & 82 & 46,57 & 3,61 & 0,82 \\
\hline Minimum & & 46,28 & 2,53 & 0,81 \\
Maximum & & 48,10 & 4,20 & 0,83 \\
\hline
\end{tabular}

Note. Average percentage of transport time and quality in each run of the simulation 
The maximum average seasonal inventory was obtained in combination 14 (producer: package; agroindustry: corrugated boxes; wholesale: plastic cage; and retailers: wooden boxes) with a value of 48.10 tons (Table 6). From the foregoing, it follows that, in the first case, each actor uses a type of packaging that reduces the symmetrical seasonal inventory average of the SC, the costs of warehousing, and the quality loss in the product. In the second case, the asymmetry in the type of packaging increases the average seasonal inventory of the SC, which increases the risks associated with product quality from $82 \%$ in packaging combination 3 to $80 \%$ in combination 14 . The transport flow time increases or decreases according to the packaging combination; for packaging combination 3 , the average transport flow time of an employee was 3.45 $\%$, unlike combination 14 , which was $3.82 \%$. For the transport, we used as measure of performance the average flow time between agents of the supply chain, for each type of packaging.

Therefore, the behavior obtained through the transportation simulation shows that the combination of the packaging type with the greatest average flow time (Fig. 3, simulation 13), is producer: plastic cage, agribusiness: plastic cage, wholesaler: package, and retailer: plastic cage. Figure 4 (simulation 64) represents the lowest average transportation flow time with the following packaging type combination: producer: corrugated boxes, agro-industry: wooden boxes, wholesaler: corrugated boxes, and retailer: wooden boxes. The average flow time among the SC actors determines the delays in transport capabilities at each link of the SC.

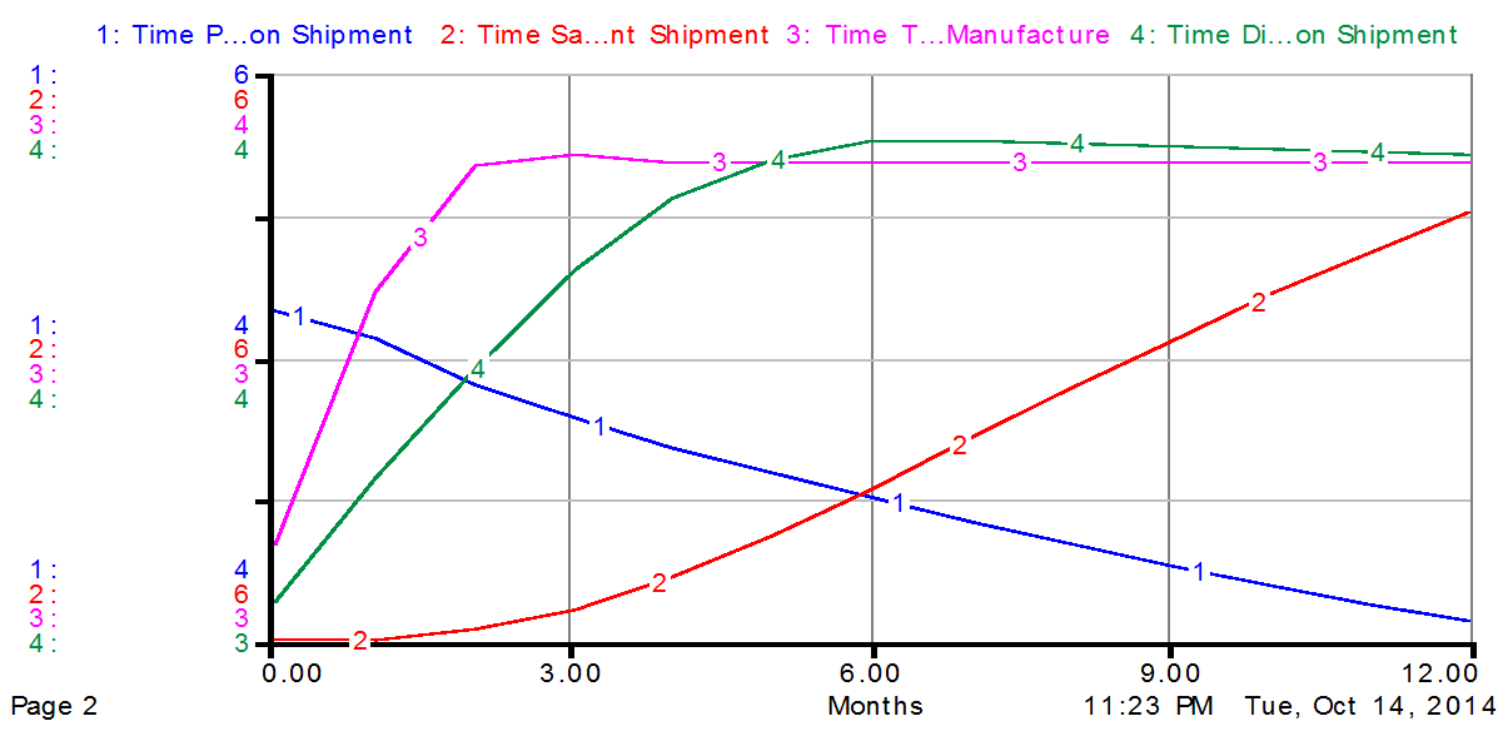

FIG. 3. Asymmetric behavior of transport time simulation associated with the type of packaging. Simulation 13, and packaging combination 1.

To compare the percentage of time the SC actor spent on mango packaging (Table 4), and the packaging type combinations with higher and lower flow time in the transport sector (Table 6), see Figure 3. The percentages of the average time used for packaging mango with simulation 64 (packaging combination 13) and simulation 13 (packaging combination 1) for each actor (producer, 1; agribusiness, 2; wholesaler,
3; and retailer, 4) display a stable behavior for the agribusiness, wholesaler, and retailer actors using packaging combination 13 (average percentage packaging time of $0.5 \%$ ), and a cyclical behavior using packaging combination 1 (average percentage packaging time of $0.25 \%$ ) in the transportation sector for the four SC actors. 


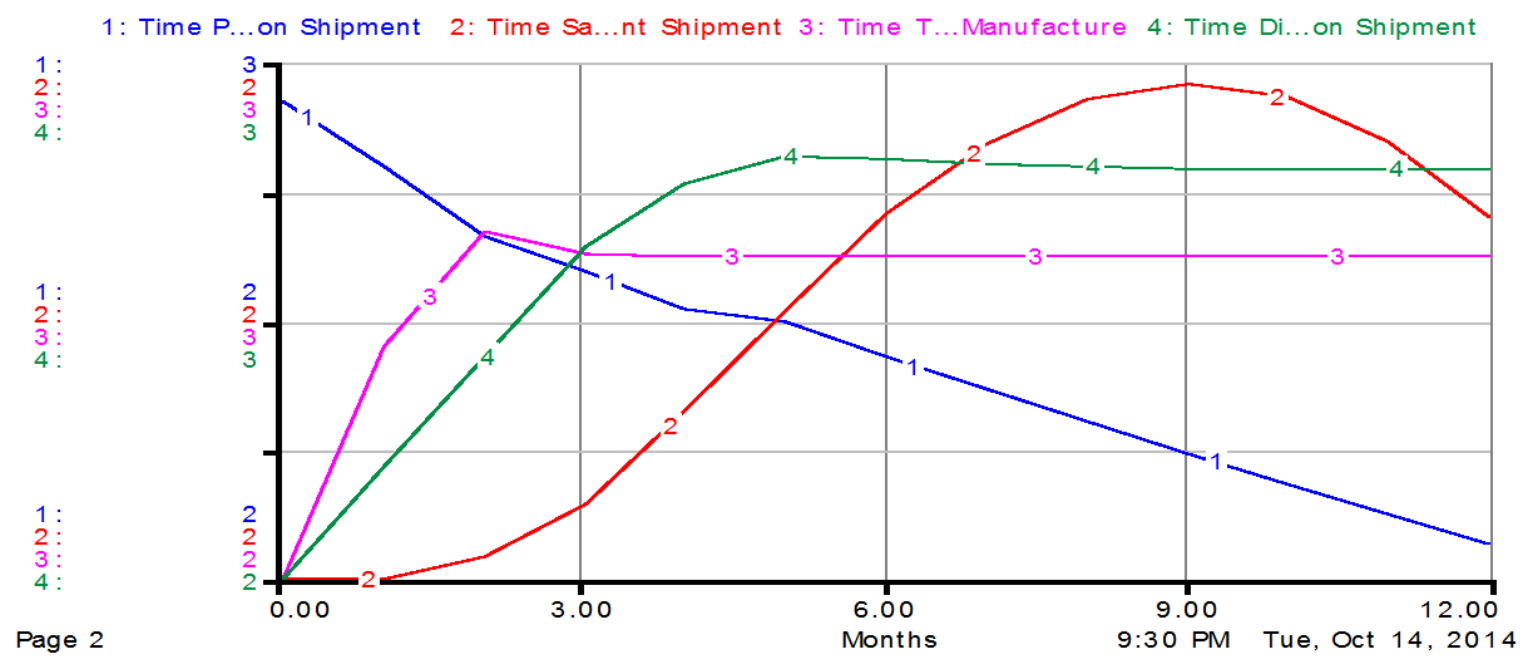

Fig. 4. Symmetrical behavior of transport time simulation associated with the type of packaging. Simulation 64, and packaging combination 13 .

The combination of the packaging type used by the mango SC actors in Figure 4 and Table 7 is defined by the design of plastic baskets in simulation 64 , and wooden and corrugated boxes in simulation 13 .

\section{TABLE 7}

Analysis of Asymmetries According to the Type of Packaging Used in the Fruit SC

\begin{tabular}{|c|c|c|c|c|c|c|c|c|}
\hline Simulation & Producer & $\begin{array}{c}\text { Agribusiness } \\
\text { transformer) }\end{array}$ & $\begin{array}{c}\text { Market } \\
\text { wholesalers }\end{array}$ & $\begin{array}{c}\text { Retail } \\
\text { trader } \\
\text { average } \\
\text { seasonal } \\
\text { inventory } \\
\text { The } \\
\text { average } \\
\text { flow time } \\
\text { in the } \\
\text { transport } \\
\text { sector }\end{array}$ & $\begin{array}{c}\text { Quality and } \\
\text { Traceability } \\
\%\end{array}$ & $\begin{array}{c}\text { Trend } \\
\text { Packaging } \\
\text { employee }\end{array}$ \\
\hline 15 & $\begin{array}{c}\text { Corrugated } \\
\text { box (2) }\end{array}$ & $\begin{array}{c}\text { Plastic cage } \\
(3)\end{array}$ & $\begin{array}{c}\text { Plastic cage } \\
(3)\end{array}$ & $\begin{array}{c}\text { Plastic } \\
\text { cage (3) }\end{array}$ & 46,28 & 0,43 & 82 & 3 \\
\hline 77 & $\begin{array}{c}\text { Package (4) } \\
\text { Corrugated } \\
\text { box (2) }\end{array}$ & $\begin{array}{c}\text { Plastic cage } \\
(3)\end{array}$ & $\begin{array}{c}\text { Wooden } \\
\text { box (1) }\end{array}$ & 48,10 & 0,5 & 81 & - \\
\hline 13 & $\begin{array}{c}\text { Plastic cage } \\
(3)\end{array}$ & $\begin{array}{c}\text { Plastic cage } \\
(3)\end{array}$ & Package (4) & $\begin{array}{c}\text { Plastic } \\
\text { cage (3) }\end{array}$ & 46,42 & 0,5 & 81 & 3 \\
\hline
\end{tabular}

The results of simulation 15 (Table 7) show a lower value in the seasonal inventory average (46.28 tons), and a quality percentage of $82 \%$. Simulation 13 , which shows the combination of corrugated and wooden boxes by the different SC actors, resulted in a better quality percentage ( $83 \%$ ) (Table 7). Similarly, the average transportation flow time in this combination (corrugated boxes and wooden crates) is smaller than the one of simulation 77 (package, corrugated boxes, plastic crates, and wooden boxes), and 64 (plastic crates and packages). The homogenization and standardization of packaging by the logistics sector in terms of size or type of material is elucidated by the results obtained in this investigation. This implies the importance of packing in the chain, and is contrary to the current decisions made by the operators about using their available means. Therefore, collaboration, cooperation, or coordination with the various upstream links is necessary to ensure that the savings generated 
by the efficiencies are distributed for the benefit of producers and the weakest links in the chain.

\section{Conclusions}

The system dynamics model allowed us to analyze the behavior of the packaging in the links of the mango supply chain (fruit producer, wholesale marketer, agribusiness, and market retailer). From the primary information, the formulation of the problem, and the dynamic hypothesis, we developed a simulation model composed of seven sectors of simulation that represented the flow of information and materials associated with logistics, packaging, warehouses, and transportation in the mango supply chain.

The type of packaging used by the SC actors affects the inventory levels, transportation flow time, and quality of the products. Coordination at the inter-links is a fundamental aspect of improving performance measures in packaging, inventories, and transportation of the fruit SC. The results of the simulation (Tables 5,6 and 7) show that the selection of the packaging types, according to the requirements of the chain, generated less inefficiency.

Repackaging operations increase the average seasonal inventory, and the average transportation flow time, and decreases the products quality. In this sense, the combination of this simulation and the type of packaging used underlined the symmetry of the packaging, and the better performance in regard to the measures of seasonal inventory, transportation time, and quality. The asymmetry of the packaging and the change (repackaging) between the actors negatively impacts the storage, transportation, and quality of products. It was shown that the hypothesis is accepted since the decline of asymmetries in the packaging allows for the improvement of the logistics performances of inventories, transportation, and quality, which is achieved through decisions made by actors when packing for the mango SC, and not for their own link depending on available resources.

\section{Future WORK}

The model can be replicated in productive chains of other fruits. Likewise, other measures of logistics performance, such as the capacity of trucks, warehouses, and rammers, among other logistical means can be used. It is necessary to carry out studies on the incidence of coordination, cooperation, and collaboration in the performance of the fruit logistics chain. It is also necessary to evaluate factual ways in which preliminary solutions proposed by ICONTEC are valid in the context of the chain, the culture of the actors, and the mango requirements, all of which are compared to the sizes and types of packaging required for the domestic and export markets.

\section{REFERENCES}

[1] O. J. Caleb, U. L. Opara, and C. R. Witthuhn, "Modified Atmosphere Packaging of Pomegranate Fruit and Arils: A Review," Food and Bioprocess Technology, vol. 5 (1), pp. 15-30, Jan. 2012. DOI: http://doi.org/10.1007/s11947-011-0525-7.

[2] M. Yu and A. Nagurney, "Competitive food supply chain networks with application to fresh produce," Europea Journal Operation Research, vol. 224 (2), pp. 273-282, Jan. 2013. DOI: http://doi.org/10.1016/j. ejor.2012.07.033.

[3] Arshinder, A. Kanda, and Deshmukh, "Supply chain coordination: Perspectives, empirical studies and research directions," International Journal of Production Economics, p. 326, 2008.

[4] M. Cao and Q. Zhang, "Supply Chain Collaboration: Roles of Interorganizational Systems, Trust, and Collaborative Culture," Springer Science \& Business Media, 2012.

[5] H. Moharana, J. S. Murty, S. K. Senapati, and K. Khuntia, "Coordination, collaboration and integration for supply chain management," International Journal of Interscience Management Review, vol. 2 (2), pp. 46-51, 2012.

[6] M. Hudnurkar and U. Rathod, "Collaborative supply chain: insights from simulation," International Journal of System Assurance Engineering and Management, vol. 3 (2), pp. 122-144, Jun. 2012. DOI: http://doi.org/10.1007/s13198-012-0114-9.

[7] A. Arshinder, A. Kanda, and S. Deshmukh, "A coordination theoretic model for three level supply chains using contracts," Indian Academy of Science, vol. 34 (5), pp. 767-798, 2009. DOI: http://doi. org/10.1007/s12046-009-0045-6.

[8] J. Gustavsson, C. Cederberg, U. Sonesson, R. van Otterdijk, and A. Meybeck, "Global food losses and food waste," FAO, Rome, Italy, 2011.

[9] J. A. Orjuela-Castro, C. A. Castañeda-Calderón, and M. E. Calderón, “Análisis de la cadena de valor en las estructuras productivas de uchuva y tomate de árbol en la Provincia de Sumapaz y el Distrito Capital," Ingeniería, vol. 13 (2), pp. 4-12, 2008.

[10] J. A. Orjuela-Castro and I. A. Chavarrio-Colmenares, "Caracterización de la Cadena de Abastecimiento de Panela para la Provincia de Bajo Magdalena - 
Cundinamarca-," Ingeniería, vol. 16 (2), pp. 107124, 2011.

[11] W. Adarme-Jaimes, M. D. Arango-Serna, and Í. D. Cárdenas, "Comportamientos logísticos en la distribución de última milla de productos alimenticios en Villavicencio, Colombia," Revista EIA, Escuela de Ingeniería de Antioquia, vol. 11 (21), pp. 145-156, 2014.

[12] J. A. Orjuela C, M. E. Calderón, and S. P. Buitrago, La Cadena Agroindustrial de Frutas, Uchuva y Tomate de Árbol, Bogotá, Bogota D.C: Universidad Distrital Francisco José de Caldas, 2006, p. 191.

[13] J. Joas, C. Desvignes, E. Vulcain and M. Lechaud, "Understanding links between preharvest conditions and postharvest management in production chains is one of the keys to ensuring fruit quality in commercial networks," Acta Horticulturae, vol. 880, pp. 207216x, Nov. 2010. DOI: http://doi.org/10.17660/ ActaHortic.2010.880.23.

[14] M. M. Herrera and J. A. Orjuela, "Perspective of traceability in the food supply chain: An Approach from System Dynamics," Ingeniería, vol. 19 (2), pp. 63-84, 2014.

[15] Min-Agri, "Anuario Estadístico de Frutas y Hortalizas 2007-2011 y sus Calendarios de Siembra y Cosechas Resultados Evaluaciones Agropecuarias Municipales 2011", Editorial JL Impresores LTDA., Colombia, 2012.

[16] Z. Li and C. Thomas, "Quantitative evaluation of mechanical damage to fresh fruits," Trends in Food Science and Technology, vol. 35 (2), pp. 138-150, Feb. 2014. DOI: http://doi.org/10.1016/j.tifs.2013.12.001.

[17] S. Nahmias, "Perishable Inventory Theory: A Review," Operations Research, vol. 30 (4), pp. 680-700, Aug. 1982. DOI: http://doi.org/10.1287/ opre.30.4.680.

[18] J. A. Orjuela, M. M. Herrera and W. Casilimas, "Impact analysis of transport capacity and food safety in Bogota," in Engineering ApplicationsInternational Congress on Engineering, 2015.

[19] M. Nagare, P. Dutta, and A. Kambi, "Retail Inventory Management for Perishable Products with Two Bins Strategy," International Science Index, vol. 7 (4), pp. 223-228, Apr. 2013.

[20] A. Chande, S. Dhekane, N. Hemachandra, N. Rangaraj, "Perishable inventory management and dynamic pricing using RFID technology," Sa dhana, vol. 30 (2-3), pp. 445-465, Jun. 2005. DOI: http://doi. org/ 10.1007/BF02706255.

[21] D. Arango, W. Adarme and M. A. Otero, "Supply Coordination with Information Sharing in Colombian Agri- Food PYMES," Dyna, vol. 78 (167), pp. 2013212, Jun. 2011.

[22] Z. T. Balkhi and L. Benkherouf, "On an inventory model for deteriorating items with stock dependent and time-varying demand rates," Computers \& Operations Research, vol. 31 (2), pp. 223-240,
Feb. 2004. DOI: http://doi.org/10.1016/S03050548(02)00182-X.

[23] K.-L. Hou, "An inventory model for deteriorating items with stock-dependent consumption rate and shortages under inflation and time discounting," Production, Manufacturing and Logistics, vol. 168, pp. 463-474, 2006. DOI: http://doi.org/10.1016/j. ejor.2004.05.011.

[24] O. Ahumada and J. R. Villalobos, "A tactical model for planning the production and distribution of fresh produce," Annals of Operations Research, vol. 190 (1), pp. 339-358, Oct. 2011. DOI: http://doi. org/10.1007/s10479-009-0614-4.

[25] G. M. Kopanos, L. Puigjaner, and M. C. Georgiadis, "Simultaneous production and logistics operations planning in semicontinuous food industries", Omega, vol. 40 (5), pp. 634-650, Oct. 2012. DOI: http://doi. org/10.1016/j.omega.2011.12.002.

[26] Z. Liu and A. Nagurney, "Multiperiod competitive supply chain networks with inventorying and a transportation network equilibrium reformulation," Optimization and Engineering, vol. 13 (3), pp. 471513, Sep. 2012. DOI: http://doi.org/10.1007/s11081011-9170-2.

[27] M. Van Zeebroeck, V. van Linden, H. Ramon, J. De Baerdemaeker, B. M. Nicolai, and E. Tijskens, "Review Impact damage of apples during transport and handling," Postharvest Biology and Technology, vol. 45 (2), pp. 157-167, Aug. 2007. DOI: http://doi. org/10.1016/j.postharvbio.2007.01.015.

[28] B. Soleimani and E. Ahmadi, "Measurement and analysis of truck vibration levels as a function of packages locations in truck bed and suspension," Computers and Electronics in Agriculture, vol. 109, Nov. 2014. DOI: http://doi.org/10.1016/j. compag.2014.09.009.

[29] R. Zhou, S. Su, L. Yan, and Y. Li, "Effect of transport vibration levels on mechanical damage and physiological responses of Huanghua pears," Postharvest Biology and Technology, vol. 46 (1), pp. 20-28, Oct. 2007. DOI: http://doi.org/10.1016/j. postharvbio.2007.04.006.

[30] P. M. Reyes, "A mathematical example of the two-echelon inventory model with asymmetric market information," Appied Mathematics and Computation., vol. 162, 2005.

[31] A. Nagurney and D. Li, "Equilibria and dynamics of supply chain network competition with information asymmetry in quality and minimum quality standards," Computational Management Science, 2014. DOI: http://doi.org/10.1007/s10287-0140216-8.

[32] P. Zhang, Y. Xiong, Z. Xiong, and W. Yan, "Designing contracts for a closed-loop supply chain under information asymmetry," Operations Research Letters, vol. 42 (2), pp. 150-155, Mar. 2014. DOI: http://doi.org/10.1016/j.orl.2014.01.004. 
[33] A. M. Blanco, G. Masini, N. Petracci, and J. A. Bandoni, "Operations management of a packaging plant in the fruit industry," Journal of Food Engineering, vol. 70 (3), pp. 299-307, Oct. 2005. DOI: http://doi.org/10.1016/j.jfoodeng.2004.05.075.

[34] M. Bill, D. Sivakumar, K. Thompson and L. Korsten, "Avocado Fruit Quality Management during the Postharvest Supply Chain," Food Reviews International, vol. 30 (3), pp. 169-202, Jul. 2014. DOI: http://doi.org/10.1080/87559129.2014.907304.

[35] E. C. Ailes et al., "Microbial concentrations on fresh produce are affected by postharvest processing, importation, and season," Journal of Food Protection, vol. 71 (12), pp. 2389-2397, Dec. 2008. DOI: http:// doi.org/10.4315/0362-028X-71.12.2389.

[36] G. H. Davarynejad, Z. Aryanpooya, and S. Persely, "Effect of modified atmosphere packaging on fresh sour cherry fruit quality," Acta Horticulturae, vol. 1020, pp. 143-148, Feb. 2010.

[37] Y. Kim, J. K. Brecht, and S. T. Talcott, “Antioxidant phytochemical and fruit quality changes in mango (Mangifera indica L.) following hot water immersion and controlled atmosphere storage," Food Chemistry, vol. 105 (4), pp. 1327-1334, Jan. 2007. DOI: http:// doi.org/10.1016/j.foodchem.2007.03.050.

[38] J. A. Orjuela C., A. L. Pinilla O. and J. R. Rincón, "Aplicación de la tecnología de atmósfera controlada para la conservación de la granadilla," Ingeniería, vol. 7 (2), pp. 45-53, 2001.

[39] R. Porat et al., "Modified atmosphere / modified humidity packaging for preserving pomegranate fruit during prolonged storage and transport," Acta Horticulturae, vol. 818, pp. 299-304, Mar. 2009. DOI: http://doi.org/10.17660/ActaHortic.2009.818.44.

[40] S. P. Singh, V. Chonhenchob, and J. Singh, "Life cycle inventory and analysis of re-usable plastic containers and display-ready corrugated containers used for packaging fresh fruits and vegetables," Packaging Technology and Science, vol. 19 (5), pp. 279-293, Sep. 2006. DOI: http://doi.org/10.1002/ pts. 731 .

[41] Proexport-Colombia, "Cartilla de empaques y embalajes para exportación," Proexport-Colombia, Bogotá, 2003.
[42] NTC 5422. [online]. Available: http://www. corabastos.com.co/sitio/images/documents/08Norma_Tecnica_Colombiana_5422.pdf. [cited: 20 enero 2016].

[43] J. A. Galvis and H. Arjona, "Influencia de la temperatura y el tiempo de almacenamiento en la conservación del fruto de mango (Mangífera índica L.) variedad Van Dyke Colombia," Agronomia Colombiana, vol. 19 (1-2), pp. 25-35, 2002.

[44] J. A. Galvis, H. Arjona, G. Fischer, and R. Martínez, "Using modified atmosphere packaging for storing "Van Dyke" mango (mangífera índica L) fruit Colombia," Agronomia Colombiana, vol. 23 (2), p. 269-275, 2005.

[45] NTC 1266-2. [online]. Available: https://www. scribd.com/document/58309560/NTC-1266-2Mango-Especificaciones-Del-Empaque.

[46] V. Chonhenchob and S. P. Singh, "A Comparison of Corrugated Boxes and Reusable Plastic Containers for Mango Distribution," Packaging Technology and Science, vol. 16 (6), pp. 231-237, Nov. 2003. DOI: http://doi.org/10.1002/pts.630.

[47] I. Castañeda, J. L. Canal, and J. A. Orjuela, "Caracterización de la Logística de la Cadena de Abastecimiento Agroindustrial Frutícula en Colombia," Facultad de Ingeniería, Bogotá, 2013.

[48] J. W. Forrester, Industrial Dynamics, Cambridge: Massachusetts Institute, 1961.

[49] H. Akkermans and N. Dellaert, "The rediscovery of industrial dynamics: the contribution of system dynamics to supply chain management in a dynamic and fragmented world," System Dynamic Review, vol. 21 (3), pp. 173-186, 2005. DOI: http://doi. org/10.1002/sdr.317.

[50] J. Morecroft and J. Sterman, Modeling for Learning, Portland, OR: Productivity Press, 1994.

[51] DANE, "Encuesta Nacional Agropecuaria", 2013. [online]. Available: https://www.dane.gov.co/index. php/agropecuario-alias/estadisticas-agricolas-ypecuarias-ena.

[52] Agronet, «http://www.agronet.gov.co», 2013. [online]. Available: http://www.agronet.gov.co/ agronetweb1/Estadðsticas.aspx. 